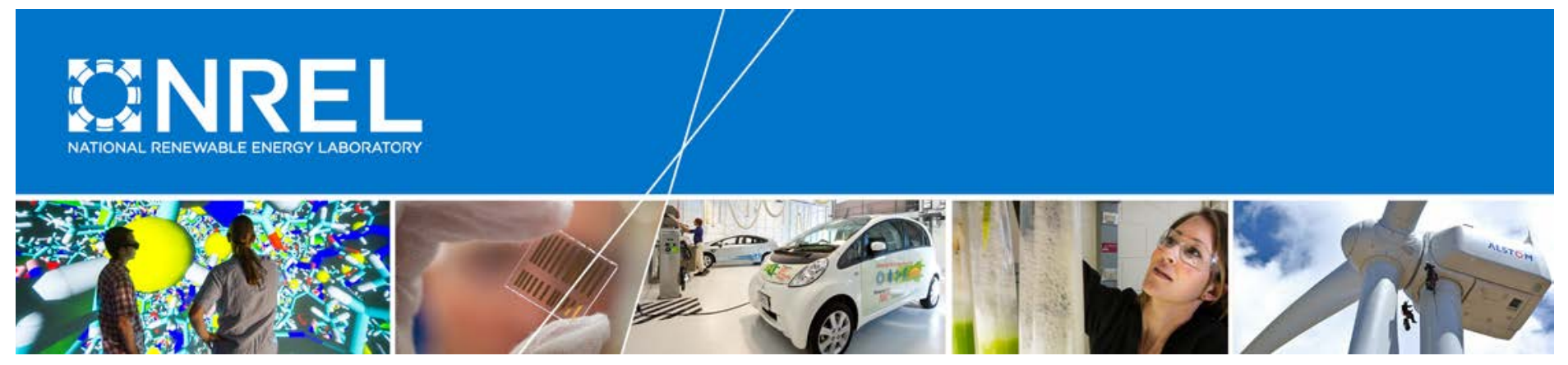

\title{
Project Summary: Community Solar Stakeholder Impacts in Cook County, Illinois
}

Jenny Heeter and Amy Hollander National Renewable Energy Laboratory

NREL is a national laboratory of the U.S. Department of Energy Office of Energy Efficiency \& Renewable Energy Operated by the Alliance for Sustainable Energy, LLC

This report is available at no cost from the National Renewable Energy Laboratory (NREL) at www.nrel.gov/publications.

Technical Report

NREL/TP-6A20-68921

August 2017

Contract No. DE-AC36-08G028308 


\section{Project Summary: Community Solar Stakeholder Impacts in Cook County, Illinois}

Jenny Heeter and Amy Hollander National Renewable Energy Laboratory

Prepared under Task No. WTSA.10675.01.01.06
NREL is a national laboratory of the U.S. Department of Energy Office of Energy Efficiency \& Renewable Energy Operated by the Alliance for Sustainable Energy, LLC

This report is available at no cost from the National Renewable Energy Laboratory (NREL) at www.nrel.gov/publications.

\section{Technical Report}

NREL/TP-6A20-68921

August 2017

Contract No. DE-AC36-08G028308
National Renewable Energy Laboratory 15013 Denver West Parkway 303-275-3000 • www.nrel.gov 


\section{NOTICE}

This report was prepared as an account of work sponsored by an agency of the United States government. Neither the United States government nor any agency thereof, nor any of their employees, makes any warranty, express or implied, or assumes any legal liability or responsibility for the accuracy, completeness, or usefulness of any information, apparatus, product, or process disclosed, or represents that its use would not infringe privately owned rights. Reference herein to any specific commercial product, process, or service by trade name, trademark, manufacturer, or otherwise does not necessarily constitute or imply its endorsement, recommendation, or favoring by the United States government or any agency thereof. The views and opinions of authors expressed herein do not necessarily state or reflect those of the United States government or any agency thereof.

This report is available at no cost from the National Renewable Energy Laboratory (NREL) at www.nrel.gov/publications.

Available electronically at SciTech Connect http:/www.osti.gov/scitech

Available for a processing fee to U.S. Department of Energy and its contractors, in paper, from:

U.S. Department of Energy

Office of Scientific and Technical Information

P.O. Box 62

Oak Ridge, TN 37831-0062

OSTI http://www.osti.gov

Phone: 865.576.8401

Fax: 865.576.5728

Email: reports@osti.gov

Available for sale to the public, in paper, from:

U.S. Department of Commerce

National Technical Information Service

5301 Shawnee Road

Alexandria, VA 22312

NTIS http://www.ntis.gov

Phone: 800.553 .6847 or 703.605 .6000

Fax: 703.605.6900

Email: orders@ntis.gov 


\section{Background}

The U.S. Department of Energy (DOE) awarded a grant to the Cook County Department of Environmental Control (Illinois) and its project team to establish replicable business models for community solar and eliminate barriers to implementation in the county. The core team included Cook County, the City of Chicago, Elevate Energy, Commonwealth Edison, West Monroe Partners, and the Environmental Law and Policy Center. DOE's National Renewable Energy Laboratory provided technical support.

The team was tasked with defining the value proposition of community solar to stakeholders in Cook County. To do this, the project team conducted multiple workshops to gain feedback from local and national stakeholders. This document summarizes the process used to evaluate stakeholder impacts of community solar in Cook County.

\section{Process for Valuing Community Solar}

Rooftop valuation studies across the country have been done to quantify the benefits of policies like net metering to the grid or to society as a whole; in many cases, these studies are done to provide rational for continuing net metering policies. Community solar valuation is similar to rooftop PV valuation, with greater project sizes but typically also being sited behind the meter like rooftop PV. Cook County's project team reviewed existing PV valuation studies and developed a spreadsheet tool to value community solar to the project developer and the community solar subscriber. ${ }^{1}$ However, the tool did not address impacts to existing electricity suppliers or other stakeholders (e.g. non-community solar participants, existing electricity generators).

To assess the value of community solar in Cook County, first, the Illinois market had to be considered. The Illinois market is somewhat unique in that the utilities only serve transmission and distribution (wires only) utilities, and long-term generation and capacity contracts are procured on their behalf by the Illinois Power Agency. ComEd and the Alternative Retail Electricity Suppliers (ARES) purchase short-term energy and capacity from PJM to meet

\footnotetext{
${ }^{1}$ The Community Solar Costing Tool is a spreadsheet based tool that allows users to see the costs and benefits of community solar project to a system developer and a system subscriber.
} 
customer load requirements. Figure 1 summarizes the Illinois power market structure.

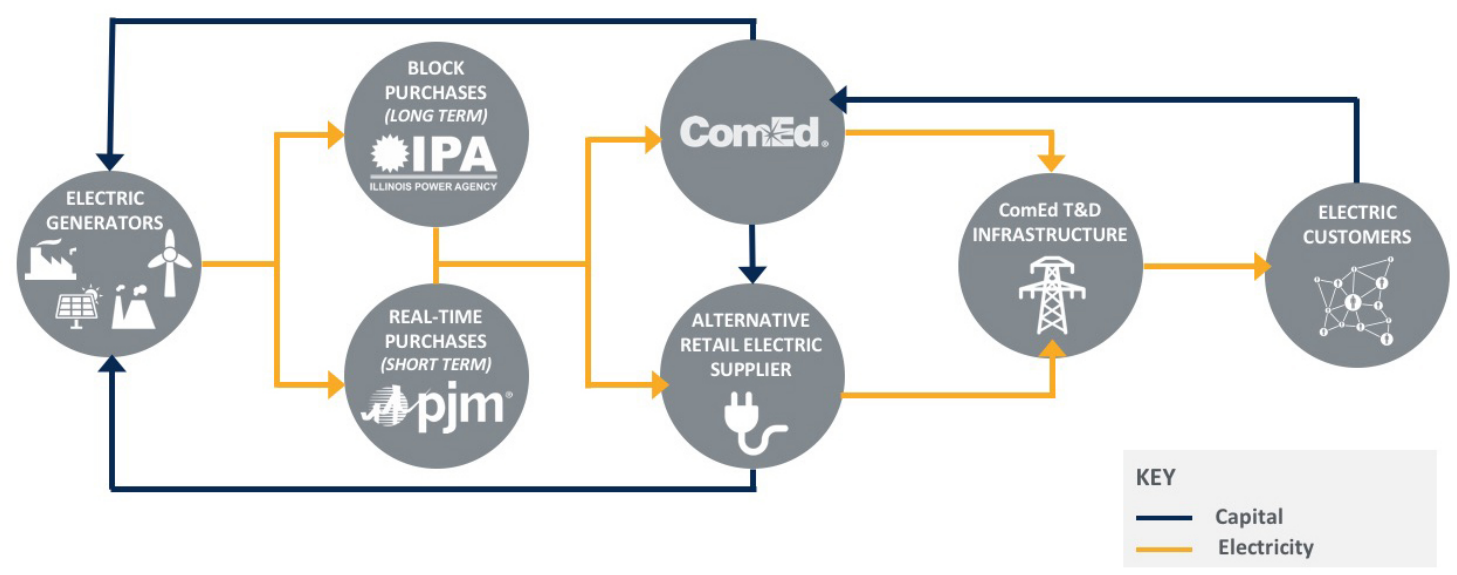

Figure 1. Illinois power market structure

Source: McGavisk and South (2017)

Then, the team worked with the local utility and regional transmission organization (RTO) to understand how the costs and benefits of community solar accrue to different stakeholders in the Illinois electricity market.

The project team organized an advisory group to shape the inputs to the valuation model. The group included stakeholders with expertise about Illinois energy markets, rate structures, and policies, as well as stakeholders with a national perspective on solar valuation and community solar (Table 1). Additional national expertise was also elicited via a webinar and review process.

Table 1. Local Stakeholder Advisory Group Participants

\begin{tabular}{|l|l|}
\hline Organization & Role \\
\hline Cook County government & Project coordinator \\
\hline Illinois Commerce Commission & Public utilities regulator \\
\hline Commonwealth Edison Company & Transmission and distribution utility \\
\hline Illinois Power Agency & Generation purchaser \\
\hline Environmental Law \& Policy Center & Environmental advocacy non-governmental organization \\
\hline PJM & Regional transmission organization \\
\hline U.S. Department of Energy & Project funder \\
\hline National Renewable Energy Laboratory & Technical expert \\
\hline West Monroe Partners & Valuation model developer \\
\hline National Regulatory Research Institute & Regulatory expert \\
\hline
\end{tabular}

The project team held two workshops, one in person and one virtual, to discuss the following key questions: 
- Which stakeholders should be included in the valuation framework?

- Which value categories are important to include?

- How can those values categories be monetized?

- How are these values assigned to a diverse group of stakeholders?

\section{Scope Considerations}

Existing literature focuses on distributed generation, but not community solar specifically. Some stakeholders raised the issue of whether a community solar project provides benefits to the grid given that community solar purchasers are not likely to be located on the same feeder as the community solar projects. There were also questions about whether the evaluation should be done for one single community solar array or for a portfolio of community solar projects.

A larger question was whether the valuation would examine all of the benefits of a community solar array to all stakeholders or would consider only the benefits that would be monetized in the Illinois market context. One stakeholder stated that there are two emerging ways in which solar valuation is occurring. The first is a method to examine all of the benefits that solar brings to the grid, including non-energy health and resource benefits, over the useful life of the resource (e.g., 25 years). This approach is being used by a separate DOE project in Rhode Island, and has been used to develop "value of solar" studies around the country. The second approach is one that examines only the "price of solar" analysis, which looks at what prices solar can earn in the existing market structure.

Data availability was also a key consideration. Stakeholders acknowledged during the workshop that there were some value components with likely small impacts that would be time consuming to quantify. As such, the team agreed to move forward without quantifying those pieces but to acknowledge them qualitatively.

\section{Stakeholder Input}

The project considered benefits from avoided generation costs, avoided transmission and distribution (T\&D) costs, risk mitigation, and environmental improvements. Each category in 
Figure 2 was reviewed and discussed during the workshops.
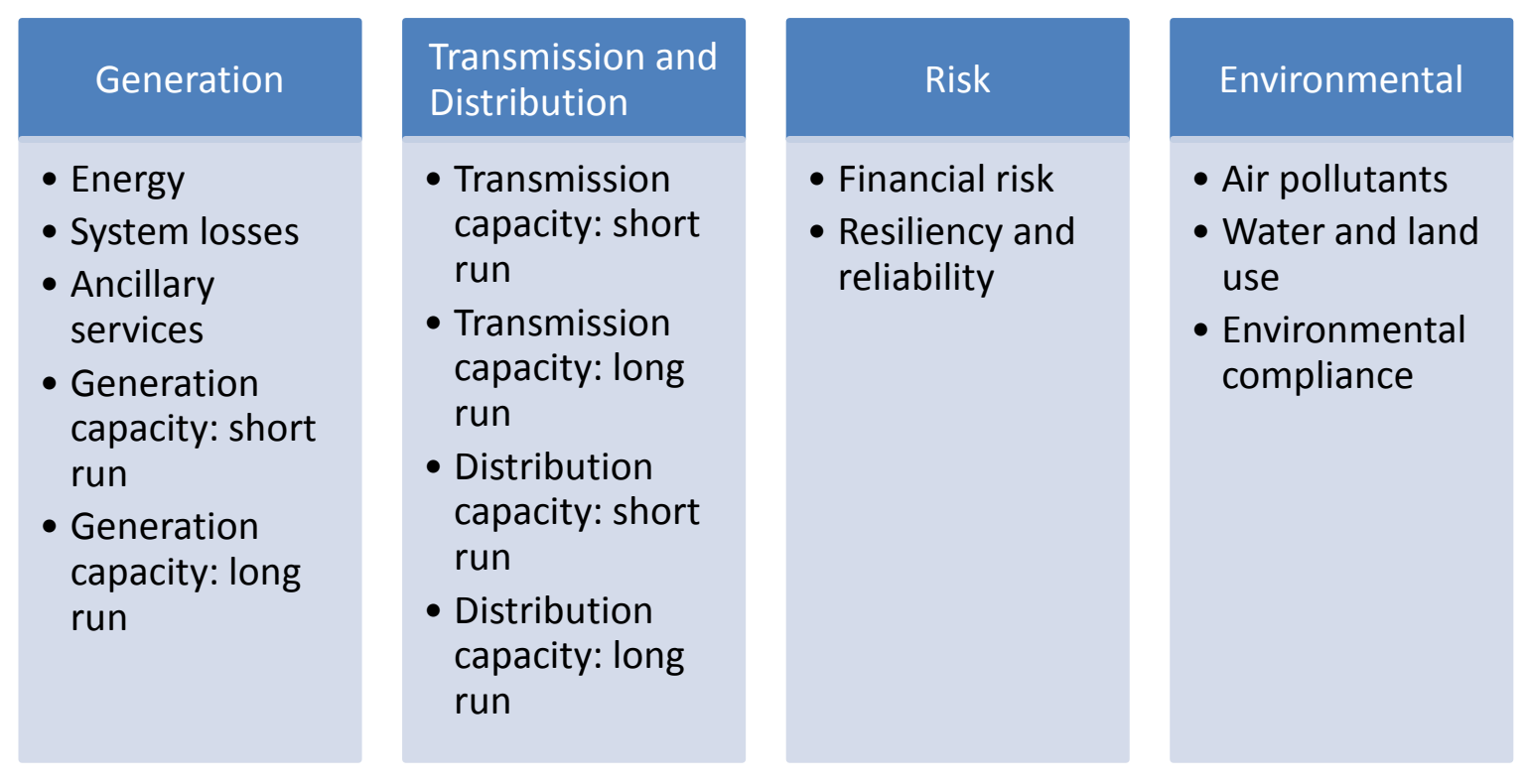

Figure 2. Community solar valuation categories addressed

West Monroe Partners defined the directional solar benefits under the current Illinois rate structure. They documented who benefitted from individual value categories. Stakeholders included solar developers, community solar subscribers, the T\&D utility, electric customers, ARES, electric generators, the RTO, and society. This framework was reviewed with the working group to help understand the Illinois-specific context of how solar benefits could be monetized. By the end of the working group session, the directional matrix had been revised for both the existing rate structure and the structure outlined by the recently passed Future Energy Jobs Act (Figure 3). 


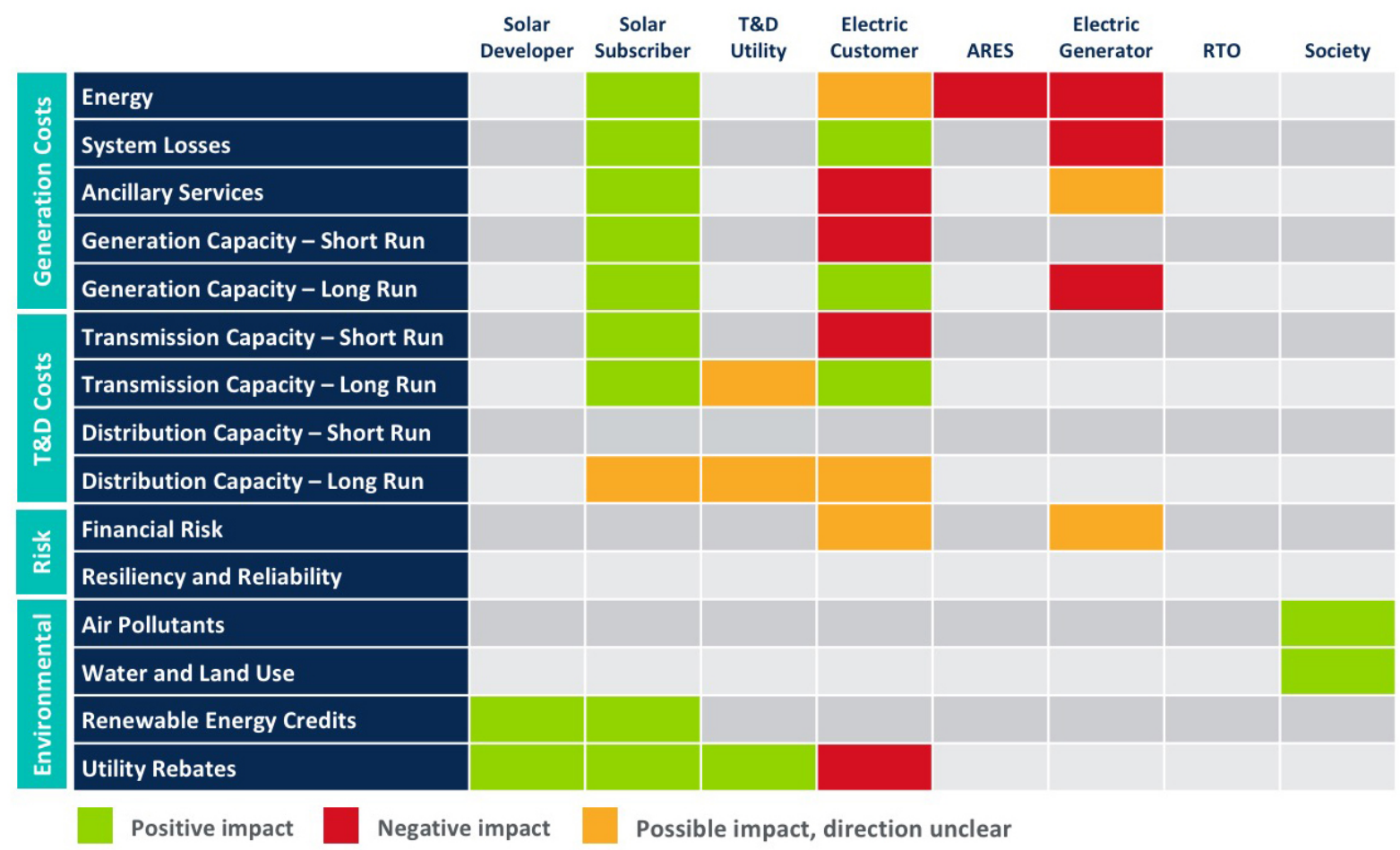

Figure 3. Directional community solar benefits under Future Energy Jobs Act

Source: McGavisk and South (2017)

\section{Evaluation Methodologies}

West Monroe Partners gathered information from literature (primarily Denholm et al. 2014 and RMI 2013) and working group participants to inform their evaluation methods. The following sections describe benefit categories considered and methodology used to quantify those benefits. Additional detail is available in West Monroe Partners (2017).

- Energy generation: Avoided energy generation represents the cost of energy that would have otherwise been generated to meet customer needs, largely driven by the variable costs of the marginal resource that is displaced. In the Illinois context, the team used PJM locational marginal pricing to set prices for energy purchases and sales in the PJM market and to price transmission congestion costs. These prices can be matched with simulated hourly PV output to determine the avoided energy costs.

- Energy losses: Avoided energy losses are the compounded value of the additional energy generated by central plants that would otherwise be lost due to inherent inefficiencies (electrical resistance) in delivering energy to the customer via the transmission and distribution system. The team used the average combined loss rate from ComEd's 2015 Distribution System Loss Study of 6-7\%.

- Ancillary services: Grid support services, commonly referred to as ancillary services in wholesale energy markets, enable the reliable operation of interconnected electric grid 
systems. The team determined that the impact of one community solar array on ancillary services, either positive or negative, would be minimal and difficult to quantify.

- Capacity: Avoided generation, transmission, and distribution capacity include capacity investments that could be deferred or avoided due to the addition of the solar system. The team recognized two components for the valuation of avoided generation capacity displaced by community solar. First, the amount of capacity that can be avoided is equivalent to the expected generation at peak load conditions. PJM analysis for 2016 suggests that $34 \%$ of solar AC nameplate rated capacity can contribute to the capacity requirements in ComEd. Second, the valuation of avoided capacity should be proportional to the capital cost of the avoided capacity. For avoided generation capacity, the team used historic PJM capacity market prices with an escalator applied to account for required reserves. ${ }^{2}$ Avoided transmission capacity and avoided distribution capacity were either not quantified or very small cost transfers. For full methodology, see West Monroe Partners (2017).

- Air pollution: The value of air pollution represents the value from reducing carbon emissions and criteria air pollutant emissions and is driven by the emission intensity of displaced marginal resource and the market price of emissions, and/or the cost of human health damages. The team used data from PJM's Generation Attribute Tracking System (GATS) to assess the avoided emissions, then placed a monetary value on the avoided emissions.

- Renewable energy certificates (RECs): RECs represent the clean energy benefits of electricity generated from the community solar energy system. Each time a solar energy system generates 1 MWh of electricity, a solar REC, or SREC, is issued. The SREC can then be sold or traded separately from the underlying power. Solar developers will be able to sell their SRECs in the Illinois Power Agency's SREC market. West Monroe Partners modeled SREC prices based on a developer receiving a 10\% internal rate of return, which resulted in $\$ 45 / \mathrm{MWh}$ SREC pricing.

- Utility rebates: Under the Future Energy Jobs Act, ComEd is required to pay rebates of $\$ 250 / \mathrm{W}$ until a 5\% net metering cap is reached. ComEd earns a rate of return on these rebates.

\section{Illinois Electricity Market Considerations}

While other studies have evaluated the costs and benefits of distributed solar, the team was interested in understanding the cost and benefit flows to different stakeholders. There are a few unique considerations for the Illinois electricity market:

- Stakeholders impacted by avoided generation. In Cook County, the T\&D utility, ComEd, sees impact of community solar only through avoided transmission capacity and distribution capacity. The electric generators and ARES see decreases in revenue if electric customers subscribe to a community solar array.

- Calculating avoided generation impacts. Avoided generation in a market like Illinois can be calculated by extrapolating hourly energy prices published by PJM. The impact on

\footnotetext{
${ }^{2} \mathrm{PJM}$ capacity market prices are available at http://www.pjm.com/markets-and-operations/rpm.aspx.
} 
the ARES can be calculated by multiplying out the percent market share for the ARES by the margin that ARES make on supplied electricity.

- Participation in ancillary services markets. Solar is eligible to participate in some ancillary services markets in PJM; however, because of the small scale of community solar projects (i.e., under $2 \mathrm{MW}$ ), it is unlikely that they would participate.

\section{Path Forward and Study Replication in Other Markets}

Unlike other solar valuation studies, the Cook County project valuation was not part of a rulemaking or public utilities commission proceeding. West Monroe Partners finalized their value proposition analysis (West Monroe Partners 2017) and then began examining the local economic and environmental impacts of community solar deployment in Cook County.

Community solar is a growing market and entities around the country may be interested in replicating the process undertaken for Cook County. This process provides an example of how collaboration between stakeholders can inform a valuation study. While stakeholders in some cases had differing opinions, bringing the group together allowed for a good exchange of ideas and a productive exchange of available data to quantify value streams. In other markets, different stakeholders may need to be included depending on the regulatory and incentive structure, but the process for gathering data and feedback is widely replicable.

\section{Acknowledgments}

The authors acknowledge Elevate Energy's Vito Greco and West Monroe Partner's Emily McGavisk and David South, who led the community solar valuation process since August of 2016, and contributed to this publication through peer review. Their work continues with the development and maintenance of the Community Solar Costing Tool, developed with funds from the U.S. Department of Energy's SunShot program.

The authors also thank the Institute for Sustainable Communities for its leadership and management of the 2015-2017 Solar Market Pathways SunShot Initiative, which funded the Cook County valuation study, stakeholder process and publication of this report.

Finally, the authors thank the Clayton Barrows, Jaquelin Cochran, and David Mooney of NREL for their review of this report.

\section{References}

Denholm, Paul, Robert Margolis, Bryan Palmintier, Clayton Barrows, Eduardo Ibanez, Lori Bird, and Jarett Zuboy. 2014. Methods for Analyzing the Benefits and Costs of Distributed Photovoltaic Generation to the U.S. Electric Utility System. NREL/TP-6A20-62447. Golden, CO: National Renewable Energy Laboratory. http://www.nrel.gov/docs/fy14osti/62447.pdf.

McGavisk, Emily and David South. 2017. "Community Solar Economic Value Proposition." West Monroe Partners.

RMI (Rocky Mountain Institute). 2013. A Review of Solar PV Benefit \& Cost Studies: $2^{\text {nd }}$ Edition. Boulder, CO: Rocky Mountain Institute. https://rmi.org/wp- 
content/uploads/2017/05/RMI_Document_Repository_Public-Reprts_eLab-DER-Benefit-CostDeck 2nd Edition131015.pdf.

West Monroe Partners. 2017. Community Solar Economic Value Proposition. Chicago: Cook County. https://www.cookcountyil.gov/sites/default/files/service/cook-county-smp-task-5-1value-proposition-report.pdf. 